\title{
Model Remated (Realistic Mathematic Education): MeningkatKan Hasil Belajar Matematika Materi Pengukuran
}

\author{
Anjar Pujayastri ${ }^{(1)}$ \\ ${ }^{1}$ SDN Sentul 2 Blitar \\ Email: ${ }^{1}$ anjarpujayastri@gmail.com, \\ DOI: https://doi.org/10.28926/riset_konseptual.v2i2.49
}

\begin{abstract}
ABSTRAK
Peningkatan hasil belajar matematika materi pengukuran melalui model REMATED (Realistic Matematic Education) pada kelas VI B SDN Sentul 2 Kota Blitar. Penelitian ini bertujuan untuk mendiskripsikan peningkatkan hasil belajar matematika materi pengukuran melalui model REMATED pada siswa kelas VI B SDN Sentul 2 Kota Blitar. Pendekatan yang digunakan pada penelitian ini pendekatan deskriptif kualitatif. Jenis penelitian yang digunakan adalah Penelitian Tindakan Kelas (PTK) yang terdiri dari 2 siklus masing-masing terdiri dari dua pertemuan. Setiap siklus dilaksanakan dengan tahapan perencanaan, pelaksanaan, pengamatan, dan refleksi. Teknik pengumpul data dilakukan dengan instrumen lembar observasi, instrumen tes, dan dokumentasi hasil belajar. Dilihat dari hasil ketuntasan belajar kognitif siswa mengalami peningkatan setelah diterapkannya model REMATED yakni pada siklus I pertemuan 1 presentasi $58 \%$ pertemuan 2 menjadi $67 \%$ sedangkan pada siklus II pertemuan $183 \%$ pada pertemuan 2 menjadi $100 \%$.
\end{abstract}

Kata kunci: hasil belajar, pengukuran, remated,

\section{PENDAHULUAN}

Matematika merupakan ilmu yang banyak digunakandalam berbagai disiplin ilmu..Banyak pengembangan ilmu lain menggunakan konsep dasar matematika, misalnya teknologi informasi, astronomi, geologi dan sebagainya. Pentingnya dalam berbagai ilmu ini mendorong urgensi pembelajaran matematika sejak dini. Oleh karena itu pelajaran matematika diberikan kepada anak sejak pendidikan prasekolah. Daryanto (2013:157) mengemukakan bahwa matematika merupakan salah satu mata pelajaran yang dinilai cukup berperan penting dalam membentuk siswa yang berkualitas, karena matematika merupakan sarana berpikir untuk mengkaji sesuatu secara logis dan sistematis.

Matematika merupakan mata pelajaran yang memerlukan konsep-konsep matang agar siswa dapat menerimanya. Pembelajaran matematika di lapangan banyak menemui kendala antara lain kurangnya pemahaman konsep dan cara mengajar yang kurang tepat. Faktor kurangnya pemahaman konsep disebabkan banyak hal, misalnya siswa tak mempelajari sendiri konsep-konsep yang harus mereka pahami karena konsep diberikan secara langsung oleh guru tanpa melalui proses penemuan. Selain itu masih banyak belajar dengan cara konvensional yang lebih banyak menghafalkan rumus daripada memahami konsep. Faktor cara mengajar yang kurang tepat misalnya kecenderungan guru lebih banyak mengajar dengan metode ekspositori dimana pembelajaran berpusat pada guru dan siswa tidak terlibat secara aktif, sehingga mereka tidak menemukan pengalaman baru. Untuk membekali anak didik agar dapat berpikir logis, kritis, kreatif dan analistis, pelajaran matematika perlu diberikan sejak dini utamanya dari sekolah dasar. Matematika juga dapat menjadikan siswa mampu memperoleh, mengelola, dan memanfaatkan informasi untuk menjalani kehidupan yang dinamis, tidak pasti dan kompetitif.

Pembelajaran pada sekolah dasar sering mengalami banyak permasalahan, diantaranya tidak tercapai tujuan pembelajaran yang diharapkan secara optimal seperti 
halnya pembelajaran matematika pada materi pengukuran di kelas VIB Semester I SDN Sentul 2 Kota Blitar. Kenyataan di lapangan menunjukkan bahwa hasil belajar matematika siswa kelas VI B SDN Sentul 2 Tahun Pelajaran 2017/2018 khususnya pada materi pengukuran ada kesulitan dalam menghubungkan antar satuan untuk menyetarakan satuan ukur, yang pada akhirnya berdampak pada kegiatan siswa dalam pembelajaran siswa tidak aktif dan malas mengerjakan soal yang diberikan. Guru hanya menggunakan ceramah dan kurang melibatkan siswa dalam proses pembelajaran, sehingga siswa kurang tertarik mengikuti kegiatan pembelajaran. Hal ini dapat dilihat dari hasil belajar siswa masih banyak mendapat nilai kurang dari KKM dari 24 siswa yang memperoleh nilai di atas KKM hanya 6 siswa (25\%) dan 18 siswa (75\%) memperoleh nilai di bawah KKM. Berkaitan dengan rendahnya hasil belajar siswa tentang materi pengukuran, maka salah satu model pembelajaran yang sesuai untuk digunakan adalah model pembelajaran REMATED (Realistic Mathematic Education ).

Untuk menghindari kesalah pahaman antara yang dimaksud peneliti dengan persepsi pembaca, agar tercipata arah pemikiran yang sama terhadap isi penelitian ini ,maka peneliti mendefinisikan hal-hal sebagai berikut: 1). Hasil belajar merupakan hasil dari suatu interaksi tindak belajar dan tindak mengajar (Dimyati dan Mujiono, 2002:3). Hasil belajar dapat berupa aspek kognitif, afektif dan psikomotor. Penjabaran mengenai hasil belajar yang berupa ketiga aspek tersebut dipaparkan oleh Benjamin S. Bloom. 2) Peningkatan hasil belajar adalah adanya perubahan hasil belajar menjadi lebih baik dari sebelumnya yang dapat diketahui dari hasil pada pra tindakan, siklus I ke siklus selanjutnya. 3) Menurut Yuwono, pembelajaran yang berorientasikan pada Remated dapat dicirikan oleh: a) Pemberian perhatian yang besar pada "reinvention" yakni siswa diharapkan dapat membangun konsep dan struktur matematika bermula dari intuisi mereka masing-masing. b) Pengenalan konsep dan abstraksi melalui halhal yang kongkrit atau dari sekitar siswa. c) Selama proses pematematikaan siswa mengkonstruksi gagasannya sendiri, tidak perlu sama antara siswa yang satu dengan siswa yang lainnya. d) Hasil pemikiran siswa dikonfrontir dengan hasil pemikiran siswa yang lainnya. 4) Model pembelajaran Remated (Realistic Mathematic Education), merupakan konsep pembelajaran yang menekankan antara materi pembelajaran dengan dunia kehidupan nyata, sehingga peserta didik mampu menghubungkan dan menerapkan kompetensi hasil belajar dalam kehidupan sehari-hari. 5) Penerapan model Remated adalah proses yang meliputi langkah-langkah pelaksanaan pembelajaran, dalam hal ini memahami masalah kontektual, menjelaskan masalah kontektual, menyelesaikan masalah kontektual, dan menyimpulkan. Hasil penelitian sebelumnya menunjukkan bahwa penerapan model pembelajaran Remated dapat meningkatkan hasil belajar siswa. Hal ini dapat dibuktikan dari 62,5\% menjadi $92 \%$, dan aktivitas belajar siswa dari $77 \%$ menjadi $89,5 \%$.

Berdasarkan uraian di atas, maka dapat dipaparkan tujuan dari penelitian adalah untuk mendiskripsikan bagaimana penerapkan model Remated (Realistic Mathematic Education) dalam upaya peningkatan hasil belajar siswa pada mata pelajaran matematika materi pengukuran pada siswa kelas VI B Semester I SDN Sentul 2 Kecamatan Kepanjenkidul Kota Blitar, Dan mendiskripsikan peningkatan hasil belajar matematika materi pengukuran melalaui model Remated (Realistic Mathematic Education) pada siswa kelas VI B Semester I SDN Sentul 2 Kecamatan Kepanjenkidul Kota Blitar.

\section{METODE}

Penelitian dilaksanakan di SDN Sentul 2 Kecamatan Kepanjenkidul Kota Blitar. Penelitian ini dilaksanakan pada bulan Agustus tahun 2017. Yakni siklus I pertemuan 1 dilaksanakan tanggal 4 Agustus 2017, pertemuan 2 dilaksanakan tanggal 8 Agustus 2017, siklus 2 pertemuan 1 dilaksanakan tanggal 11 Agustus 2017, pertemuan 2 dilaksanakan tanggal 15 Agustus 2017. Subyek penelitian adalah siswa kelas VI B SDN Sentul 2 Kecamatan Kepanjenkidul Kota Blitar pada semester I Tahun Pelajaran 2017/2018 dengan jumlah siswa 24 orang. Obseever terdiri atas dua orang 
guru yaitu Ibu Anjar pujayastri, S.Pd dan Ibu Ririn Dwi Astuti, S.Pd yang membantu meneliti dalam merekam proses pembelajaran dengan instrument yang telah tersedia. Mata pelajaran yang dijadikan subyek adalah mata pelajaran matematika khususnya materi pengukuran Materi ini dijadikan obyek penelitian karena pada umumnya siswa kurang teliti dalam menyelesaikan soal pemecahan masalah yang berkaitan dalam menyetaran satuan ukur.

Peneliti menggunakan model PTK yang dikembangkan oleh Kemmis dan Taggat (1900). Penelitian ini dilaksanakan sebanyak dua siklus. Peneliti menggunakan beberapa tahapan mulai dari perencanaan ,pelaksanaan, pengamatan, dan refleksi seperti yang dijelaskan oleh Arikunto (2010:17). Tahapan peneliti yang dilaksanakan oleh peneliti secara lebih rinci melalui tahap perencanaan (planing), tahap pelaksanaan (action), tahap pengamatan (observation), tahap refleksi (reflecting).

Sumber data dalam Penelitian Tindakan Kelas (PTK) ini terdiri dari beberapa sumber yaitu guru dan siswa. Data yang digunakan dalam penelitian ini adalah data hasil observasi kemampuan guru selama proses pembelajaran dengan menggunakan model pembelajaran Remated, data hasil belajar siswa yang meliputi data penilaian belajar siswa dalam aspek afektif yang diperoleh dari hasil pengamatan sikap selama proses pembelajaran dan aspek kognitif yang diperoleh dari skor hasil belajar, hasil observasi selama proses pembelajaran, dan hasil angket respon siswa serta lembar catatan lapangan

Dalam mengumpulkan data ,peneliti menggunakan instrument lembar tes dan lembar obsevasi. Data tentang hasil belajar siswa diperoleh dengan mengamati hasil pekerjaan siswa dalam proses pembelajaran. Adapun instrumen yang diperlukan Instrumen Pengamatan Aktivitas Siswa dalam PBM, Instrumen Pengamatan Aktivitas Guru dalam PBM, Rencana Pelaksanaan Pembelajaran, dan Instrumen pengumpul data. Pengumpulan data tentang proses pembelajaran diperoleh melalui pengamatan yang dilakukan oleh teman sejawat. Pengamatan dilakukan dengan menggunakan instrumen lembar observasi kualitas pembelajaran. Teman sejawat juga sekaligus memberikan nilai terhadap RPP dan kegiatan pembelajaran yang dilakukan peneliti dalam rangka menilai pelaksanaan pembelajaran.

Analisis data dilakukan setelah pelaksanaan tindakan setiap siklus. Teknik analisis data yang digunakan dalam penelitian ini adalah teknik analisa data deskriptif kualitatif yaitu reduksi data, penyajian data, dan penarikan kesimpulan. Data-data yang dianalisis dipaparkan data yang bersumber dari format observasi (guru dan siswa). Data ini menguraikan data yang dibuat pengamat. Penilaian pada obserasi guru adalah skor yang diperoleh dibagi skor maksimum dan dikalikan 100. Jika hasil yang diperoleh lebih dari $70 \%$ dari skor total maka guru sudah menerapan model pembelajaran Remated dengan baik. Data ini diambil dari nilai aktivitas siswa saat proses pembelajaran berlangsung. Penilaian aktivitas siswa diperoleh dengan skor yang diperoleh, dibagi skor maksimum dikali 100. Jika hasil yang diperoleh lebih dari $70 \%$ dari skor total maka aktivitas siswa sudah baik pada penerapan model pembelajaran Remated. Peningkatan hasil belajar dapat dilihat dari rata-rata hasil tes. Untuk peningkatan hasil belajar maka digunakan nilai yang diperoleh siswa yang disesuaikan dengan KKM sebagai indikator peningkatan hasil. Patokan ketuntasan belajar siswa adalah KKM (Kriteria Ketuntasan Minimal ). Siswa dikatakan tuntas belajar apabila nilai siswa mencapai nilai $>70$ karena KKM yang ditetapkan pada mata pelajaran matematika 70 .

Langkah-langkah analisis terdiri dari tiga alur kegiatan yang terjadi secara bersamaan yaitu reduksi data, penyajian data, dan penarikan kesimpulan. Melakukan reduksi, yaitu mengecek dan mencatat kembali data-data yang telah terkumpul, memokuskan, dan menyederhanakan data sampai penyusunan data. Data yang telah terkumpul diklsifikasikan berdasarkan jenisnya atau aspek yang diamati yang bertujuan memudahkan peneliti menarik kesimpulan. Penyajian data dilakukan dengan cara membuat membuat tabel dan narasi, lalu dibandingkan dan dipadukan dengan berbagai informasi atau data yang diperoleh dari hasil reduksi data hingga memberi 
kemungkinan adanya penarikan kesimpulan dan pengambilan tindakan. Informasi tersebut berupa uraian kegiatan pembelajaran, aktivitas siswa dalam pembelajaran, respon siswa terhadap pembelajaran, serta hasil yang diperoleh siswa. Penarikan kesimpulan adalah pengambilan inti dari data-data yang telah dikumpulkan. Penarikan kesimpulan hasil belajar dapat dilihat dari hasil ketuntasan siswa baik secara individu maupun klasikal selama pembelajaran. Langkah-langkah penelitian dimulai dengan kegiatan tahap pratindakan yang meliputi pengamatan dan rsfleksi, kemudian dilanjutkan dengan tahap tindakan yang terdiri dari 2 siklus.

\section{HASIL}

Kondisi awal kelas VI SDN Sentul 2 Kota Blitar sebelum diadakan penelitian tindakan kelas memperoleh hasil rata- rata di bawah KKM yang telah ditentukan. Hal ini karena kegiatan pembelajaran belum menggunakan model Remated (Realistic Matematic Education), melainkan menggunakan metode ceramah.

Dalam rangka meningkatkan hasil belajar materi pengukuran peneliti pada siswa kelas VI SDN Sentul 2 Kota Blitar, peneliti membuat perbaikan dengan merancang pembelajaran menjadi dua siklus.Perbaikan dilakukan dengan model pembelajaran Remated (Realistic Matematic Education).

Pelaksanaan siklus I pertemuan 1 pada tanggal 4 Agustus 2017 selama 2x35 menit. Jumlah siswa kelas VI SDN Sentul 2 saat itu semua hadir 24 siswa. Pada tahap ini guru memulai pembelajaran dengan model pembelajaran Remated. Diskripsi langkah-langkah pembelajaran sebagai penyampaian materi (memahami masalah kontektual), menjelaskan masalah kontektual, menyelesaikan masalah kontektual, membandingkan dan mendiskusikan masalah kontekstual, dan menyimpulkan. Pada siklus I Penilaian aktivitas guru menggunakan lembar observasi guru. Aspek yang diamati dalam observasi guru dengan menerapkan model Remated dari kegiatan awal, kegiatan inti dan kegiatan akhir mendapat skor $75 \%$ dengan kriteria baik. Penilaian aktivitas siswa menggunakan lembar observasi siswa. Berdasarkan data pada lembar observasi ada 6 diskriptor yang belum tampak diantaranya siswa tidak mendengarkan penjelasan guru tentang tujuan pembelajaran, siswa belum ada yang bertanya, siswa tidak semua aktif dalam berdiskusi dan siswa belum membuat catatan hasil kesimpulan. Prosentase nilai $75 \%$ dengan kriteria baik. Berdasarkan data penilaian afektif pada aspek keaktifan ada 6 siswa yang aktif, 4 siswa sedang, dan 14 siswa tidak aktif. Pada aspek kerjasama 4 siswa baik, 4 siswa kurang dan 16 siswa yang tidak mau kerja sama, sedangkan aspek partisipasi 3 siswa baik, 6 siswa kurang, dan 15 siswa tidak mau berpartsipasi. Hasil tes individu memperoleh nilai total sebesar 1620 dengan nilai rata-rata yakni 67,5 dan prosentase ketuntasan 58\%, 14 Siswa mendapat nilai di atas KKM, dan 10 siswa mendapat nilai kurang di KKM. Nilai akhir merupakan rata-rata dari nilai kelompok dan nilai tes individu. Dari 24 siswa yang tuntas sebanyak 15 siswa $(37,5 \%)$ dan tidak tuntas sebanyak 9 siswa $(62,5 \%)$, jumlah nilai 1727,5 nilai rata-rata 66 . Secara ketuntasan klasikal pembelajaran $54 \%$.

Pelaksanaan siklus I pertemuan 2 pada tanggal 7 Agustus 2017 selama 2×35 menit. Jumlah siswa 24 siswa. Penilaian aktivitas guru mendapat prosentase $79 \%$ dengan kriteria baik. Hasil observasi siswa memperoleh nilai rata-rata $83 \%$. dengan kriteria baik. Hasil penilaian afektif siswa pada aspek partisipasi terdapat 12 siswa belum tampak, 7 siswa mulai tampak dan 5 siswa yang sudah tampak. Selanjutnya pada aspek kerjasama terdapat terdapat 12 siswa yang belum tampak, 7 siswa mulai tampak dan 5 siswa sudah tampak. Pada aspek keaktifan terdapat 13 siswa belum tampak , 4 siswa mulai tampak dan 7 siswa yang sudah tampak. Hasil tes individu siswa memperoleh nilai total 1690 dengan nilai rata-rata 70,5 siswa yang tuntas 16 prosentase $67 \%$ sedangkan yang belum tuntas 8 siswa prosentase $33 \%$ dan prosentase ketuntasan adalah $67 \%$.

Pelaksanaan siklus II pertemuan 1 pada tanggal 11 Agustus 2017 selama $2 \times 35$ menit. Berdasarkan hasil observasi dari teman sejawat, keberhasilan guru dalam kegiatan proses pembelajaran masih mencapai $87 \%$ dengan kriteria sangat baik. 
Berdasarkan data pada lembar observasi siswa keberhasilan kegiatan proses pembelajaran mencapai $87 \%$ dengan kriteria sangat baik. Hasil penilaian afektif/sikap siswa pada aspek partisipasi terdapat 12 siswa yang sudah tampak, 6 siswa mulai tampak, dan 6 siswa yang belum tampak. Selanjutnya pada aspek kerjasama terdapat terdapat 11 siswa yang sudah tampak, 8 siswa mulai tampak, dan 5 siswa yang belum tampak. Pada aspek keaktifan terdapat 11 siswa yang sudah tampak, 6 siswa mulai tampak, dan 7 siswa yang belum tampak. Hasil tes individu memperoleh nilai total sebesar 1760 dengan nilai rata-rata yakni 73 dan prosentase ketuntasan 83\%. Siswa mendapat nilai di atas KKM ada 20 dan 4 siswa mendapat nilai kurang di KKM.

Pelaksanaan siklus II pertemuan 2 pada tanggal 15 Agustus 2017 selama 2x35 menit. Penilaian aktivitas guru menggunakan lembar observasi guru mencapai $92 \%$ dengan kriteria sangat baik. Berdasarkan data pada lembar observasi siswa terdapat 2 diskriptor yang belum tampak dan 22 diskriptor yang sudah tampak. Diskriptor yang belum tampak yaitu siswa tidak bertanya tentang media gambar, siswa tidak mendengarkan penjelasan kembali, dan siswa belum tampak menyampaikan ide atau pendapat. Keberhasilan mencapai prosentase 92\% (sangat baik). Hasil penilaian afektif/sikap siswa pada aspek partisipasi terdapat 12 siswa sudak tampak, 8 siswa mulai tampak, dan 4 siswa yang belum tampak. Selanjutnya pada aspek kerjasama terdapat terdapat 15 siswa yang sudah tampak, 6 siswa mulai tampak, dan 3 siswa yang belum tampak. Pada aspek keaktifan terdapat 13 siswa yang sudah tampak, 6 siswa mulai tampak dan 5 siswa yang belum tampak. Hasil tes individu memperoleh nilai total 1990 dengan nilai rata-rata 82 siswa sudah tuntas dan prosentase ketuntasan adalah $100 \%$.

\section{PEMBAHASAN}

Berdasarkan observasi, model pembelajaran Remated telah dilaksanakan sesuai dengan langkah-langkah pada rencana pelaksanaan pembelajaran. Temuan aktivitas guru pada pelaksanaan tidakan siklus I yaitu guru telah melaksanakan pembelajaran cukup baik salah satunya adalah guru telah menjelaskan kegiatan pembelajarn yang akan dilaksanakan. Guru telah memberikan informasi langkahlangkah pembelajaran model Remated kepada siswa. (membimbing siswa untuk memahami, menjelaskan, berdiskusi, dan menyimpulkan masalah konstektual). Hal itu dilakukan untuk menyiapkan dan membimbing siswa agar terlibat aktif dalam pembelajaran dan siswa memiliki motivasi dalam diri mereka untuk belajar sehingga keberhasilan belajar dapat tercapai. Pembelajaran dengan model Remated bisa dilaksanakan sesuai yang direncanakan guru.

Pembelajaran yang dilaksanakan pada sliklus I dan siklus II sesuai dengan Rencan Pelaksanaan Pembelajaran (RPP) yang telah disusun. Secara garis besar, pembelajaran pada siklus I dan Siklus II dapat diringkas yaitu guru menggali pengetahuan siswa dengan bertanya jawab untuk memahami masalah konstektual, memasang media untuk alat bantu menjelaskan, siswa melakukan diskusi, presentasi dilanjutkan untuk mengambil kesimpulan, merefleksi pelajaran yang sudah dilakukan, dan penilaian .

Penerapan model Remated pada mata pelajaran matematika materi pengukuran pada siklus I sudah berjalan dengan lancar. Guru sudah cukup baik dalam pelaksanaan pembelajaran sesuai dengan RPP yang telah dibuat sebelumnya. Peneliti mendapat nilai $75 \%$, yakni termasuk kriteria baik (B). Pertemuan 2 peneliti mendapat nilai $79 \%$, termasuk kriteria baik (B), meningkat $4 \%$ sehingga pada siklus I aktivitas guru mendapat rata-rata $77 \%$ dengan kualitas baik. Hasil observasi presentase aktivitas siswa pada siklus II pada pertemuan 1 memperoleh presentase sebesar $87 \%$ dengan kualifikasi sangat baik (A) dan pertemuan 2 mempeoleh presentase $92 \%$ dengan kualifikasi sangat baik (A), sehingga pada siklus II aktivitas siswa memperoleh rata-rata sebesar $89,5 \%$. Dilihat hasil observasi guru, membuktikan bahwa dari siklus I ke Siklus II ada peningkatan 12,5\%. Hal ini menunjukkan bahwa guru telah 
menunjukkan aktivitas yang lebih baik pada siklus II ketika menerapkan model pembelajaran Remated.

Sedangkan dari aktivitas pembelajaran siswa pada siklus I sudah tampak. Dari data yang diperoleh menunjukkan prosentase aktivitas siswa pada siklus I pertemuan 1 memperoleh prosentase $75 \%$ dengan kualifikasi baik dan pada pertemuan 2 memperoleh prosentase $83 \%$ dengan kualifikasi baik, sehingga pad siklus I aktivitas siswa memperoleh prosentase rata-rata $79 \%$. Hasil observasi presentase aktivitas siswa pada siklus II pada pertemuan 1 memperoleh presentase sebesar $87 \%$ dengan kualifikasi sangat baik $(A)$ dan pertemua 2 mempeoleh presentase $92 \%$ dengan kualifikasi sangat baik (A), sehingga pada siklus II aktivitas siswa memperoleh rata-rata sebesar $89,5 \%$. Peningkatan aktivitas siswa dari I ke siklus II ada 10,5\%. Hal ini menunjukkan bahwa siswa telah menunjukkan aktivitas yang lebih positif pada siklus II ketika diterapkan model pembelajaran Remated. Berdasarkan temuan dari yang diperoleh dari aktivitas siswa maka dapat disimpulkan bahwa penerapan model pembelajaran Remated dapat meningkatkan aktivitas siswa dalam belajar mata pelajaran matematika kelas VI SDN Sentul 2 Kota Blitar. Maka dengan pencapaian tersebut pembelajaran sudah tuntas dan tidak perlu lagi dilakukan siklus berikutnya, Hasil ini menunjukkan bahwa model pembelajaran Remated dapat digunakan untuk meningkatkan hasil belajar matematika materi pengukuran di kelas VI Semester 1 SDN Sentul 2 Kota Blitar.

\section{KESIMPULAN}

Penerapan model pembelajaran Remated pada materi pengukuran diterapkan dengan baik sesuai dengan langkah-langkah model pembelajaran Remated. Hasil belajar materi pengukuran pada kelas VI SDN Sentul 2 selalu meningkat. Dari siklus I ke siklus II hasil presentasi ketuntasan belajar mengalami peningkatan. Rata-rata hasil belajar siklus I memperoleh $62,5 \%$ dan pada siklus II menjadi $92 \%$. Dari siklus I ke siklus II meningkat 29,5\%. Sedangkan aktivitas pembelajaran siswa pada siklus I memperoleh prosentase rata-rata $77 \%$ meningkat menjadi $89.5 \%$. Dari siklus I ke siklus II meningkat $12.5 \%$. Dapat disimpulkan model pembelajarn Remated sangat cocok diterapkan pada mata pelajaran matematika materi pengukuran dapat meningkatkan aktivitas guru dan aktivitas siswa. Dilihat dari hasil ketuntasan belajar kognitif siswa mengalami peningkatan setelah diterapkannya model Remated yakni pada siklus I pertemuan 1 presentasi $58 \%$ pertemuan 2 menjadi $67 \%$ sedangkan pada siklus II pertemuan $183 \%$ pada pertemuan 2 menjadi $100 \%$. Hal ini menunjukkan bahwa terjadi peningkatan hasil belajar sesudah diberi tindakan..

\section{SARAN}

Dari hasil penelitian yang telah dilakukan, dapat dikemukakan saran-saran yaitu guru dalam meningkatkan hasil belajar siswa hendaknya menggunakan metode yang bervariasi dan menerapkan model pembelajaran yang sesuai dengan materi dan lingkungan agar pembelajaran menyenangkan dan termotivasi, dengan model Remated siswa dapat menyelesaikan permasalahan dalam kehidupan sehari hari yang berhubungan dengan jarak, waktu, kecepatan, volume, dan debit, sekolah hendaknya dapat memberikan kebijakan dalam meningkatkan mutu hasil belajar siswa, peneliti hendaknya lebih mampu melatih kreativitas, dan ketrampilan dalam menerapkan model pembelajaran Remated di sekolah dasar.

\section{DAFTAR RUJUKAN}

Arikunto ,Suharsimi, dkk. 2006. Penelitian Tindakan Kelas .Jakarta Bumi Aksara Daryanto. 2013. Inovasi Pembelajaran Efektif. Bandung: Yrama Widya.

Dimyati \& Mudjiono. 2006. Belajar dan Pembelajaran. Jakarta : Rineka Cipta.

Rusman. .Model-model Pembelajaran Mengembangkan Profesionalisme guru. Jakarta: Depdikbud. 
JURNAL PENDIDIKAN: Riset \& Konseptual

E-ISSN: $2598-2877$

http://journal.unublitar.ac.id/pendidikan/index.php/Riset_Konseptual

P-ISSN: 2598-5175

Vol. 2 No. 2, April 2018;

Wardani, I.G.A.K., Wihardi, K. \& Nasoetion. 2004. Penelitian Tindakan Kelas. Jakarta: Univesitas terbuka . 